Interfaces

\title{
Promenades poétiques et daguerriennes-Bellevue : Photography and Narration
}

\section{Margaret Fields Denton}

\section{(2) OpenEdition \\ 1 Journals}

Electronic version

URL: http://journals.openedition.org/interfaces/661

DOI: 10.4000/interfaces.661

ISSN: 2647-6754

\section{Publisher:}

Université de Bourgogne, Université de Paris, College of the Holy Cross

\section{Printed version}

Date of publication: 12 December 2019

Number of pages: $25-42$

ISSN: 1164-6225

\section{Electronic reference}

Margaret Fields Denton, "Promenades poétiques et daguerriennes-Bellevue : Photography and Narration", Interfaces [Online], 42 | 2019, Online since 12 December 2019, connection on 05 January 2021. URL: http://journals.openedition.org/interfaces/661 ; DOI: https://doi.org/10.4000/interfaces. 661

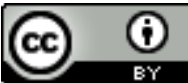

Les contenus de la revue Interfaces sont mis à disposition selon les termes de la Licence Creative Commons Attribution 4.0 International. 


\title{
PROMENADES POÉTIQUES ET DAGUERRIENNES—BELLEVUE : PHOTOGRAPHY AND NARRATION
}

\author{
Margaret Fields Denton \\ University of Richmond in Richmond, Virginia
}

\begin{abstract}
Louis-Auguste Martin's Promenades poétiques et daguerriennes--Bellevue, a brochure length work that was published in 1850, was regarded at the time as the first publication in France to combine text with photographs. Martin was both author of the poem, which recounts a weekend trip to a village near Paris, and maker of the seven paper photographs inserted between the lines of the poem. His choice of title points to his intention to situate his work within the literary tradition of the Promenade. However, Bellevue is not only a promenade poétique, but also a promenade daguerrienne which signals that the images are not mere illustrations but participants in the narration of the Promenade. This essay argues that while adheres in many ways to the conventions of the Promenade, the insertion of photographs problematizes a key element of the genre, which is the tension between the immediacy of impressions as they are experienced during the activity of travel or walking, and the subsequent composition of these impressions.
\end{abstract}

\section{Résumé}

La courte brochure Promenades poétiques et daguerriennes-Bellevue de LouisAuguste Martin, publiée en 1850, fut considérée en son temps comme le premier ouvrage en France mêlant texte et photographies. Martin était l'auteur du texte poétique, qui relate une sortie du dimanche aux environs de Paris, et l'auteur des sept photographies insérées dans le poème. Le choix du titre montre qu'il tenait à s'inscrire dans la tradition littéraire de la Promenade. Pourtant, Bellevue n'est pas qu'une promenade poétique, c'est aussi une promenade daguerrienne, qui témoigne que les images ne sont pas seulement des illustrations du texte mais participent pleinement au récit. Cet article avance que, tout en respectant à certains égards les conventions de la Promenade, le récit par l'inclusion des photographies exprime la tension inhérente à ce genre, à savoir celle qui a lieu entre l'immédiateté des impressions telles qu'elles sont ressenties lors de la marche ou du déplacement, et la recomposition de ces impressions par la suite. 
The 1865 edition of Louis Gustave Vapereau's Dictionnaire universel des contemporains identifies Louis-Auguste Martin (1811-1875) as both littérateur and sténographe (1198). As a stenographer Martin was attached to the Collège de France and the Sorbonne, and later the National Assembly. He authored several books on the mores of ancient and modern societies, some of which are listed in Vapereau's Dictionnaire. There is no mention of his three Promenades poétiques et daguerriennes that were published beginning in $1850 . .^{5}$ They were perhaps omitted because the Promenades were brochures less than twenty pages in length. Another reason may be their atypical combination of text and image for they are poems with paper photographs inserted between their lines. ${ }^{6}$ This format is unique. Martin was both a writer and an early experimenter of paper photography. In 1851 , the writer and critic Francis Wey hailed Martin's Promenades as the first publications in France illustrated by photography and thus a harbinger of the medium's future (104).

Elsewhere I have examined Bellevue (fig. 1), the first of Martin's Promenades, in the context of the aims of the Société héliographique which was founded in Paris in January of 1851 to promote the progress of photography. Martin was an active member of the society that in early 1851 was occupied with the perfection of paper processes and the establishment of a photographic printing firm in France. ${ }^{7}$ Here, I want to consider Bellevue in relation to the Promenade as a literary form and to examine the idea that the photographs are extensions of the text. Martin's choice of title clearly points to his intention to situate his work within the tradition of the Promenade; however, Bellevue is not only a Promenade poétique but a Promenade daguerrienne. It is my contention that while Bellevue does adhere in many ways to the conventions of the Promenade in the France of the first half of the nineteenth century, the inclusion of the seven photographs problematizes a key element of the genre: the tension between the immediacy of impressions as they are experienced during the activity of travel or walking, and the

5 Promenades poétiques et daguerriennes - Bellevue was published in 1850. Martin published the other two brochures in 1851. Promenades poétiques et daguerriennes-Chantilly included six photographs on paper, and Promenades poétiques et daguerriennes - Enghien-Les-Bains had six photographs as well.

6 The title is confusing to the reader familiar with the fact that daguerreotypes are unique images on a metal support. Martin's use of "daguerriennes" points to a period of transition in French photography when many practitioners were turning from daguerreotypes to paper processes. Antoine Claudet, a daguerreotypist in England, states in 1851 that the French at that time used the term "daguerréotype sur papier" (daguerreotype on paper) to refer to paper photographs. See "Société héliographique. Séance du 4 avril," La Lumière no. 11 (20 avril 1851): 42.

7 See Margaret Denton, “Louis-Auguste Martin’s Promenades poétiques et daguerriennes - Bellevue, ” History of Photography 35, no. 3 (August 2011): 207-220. 


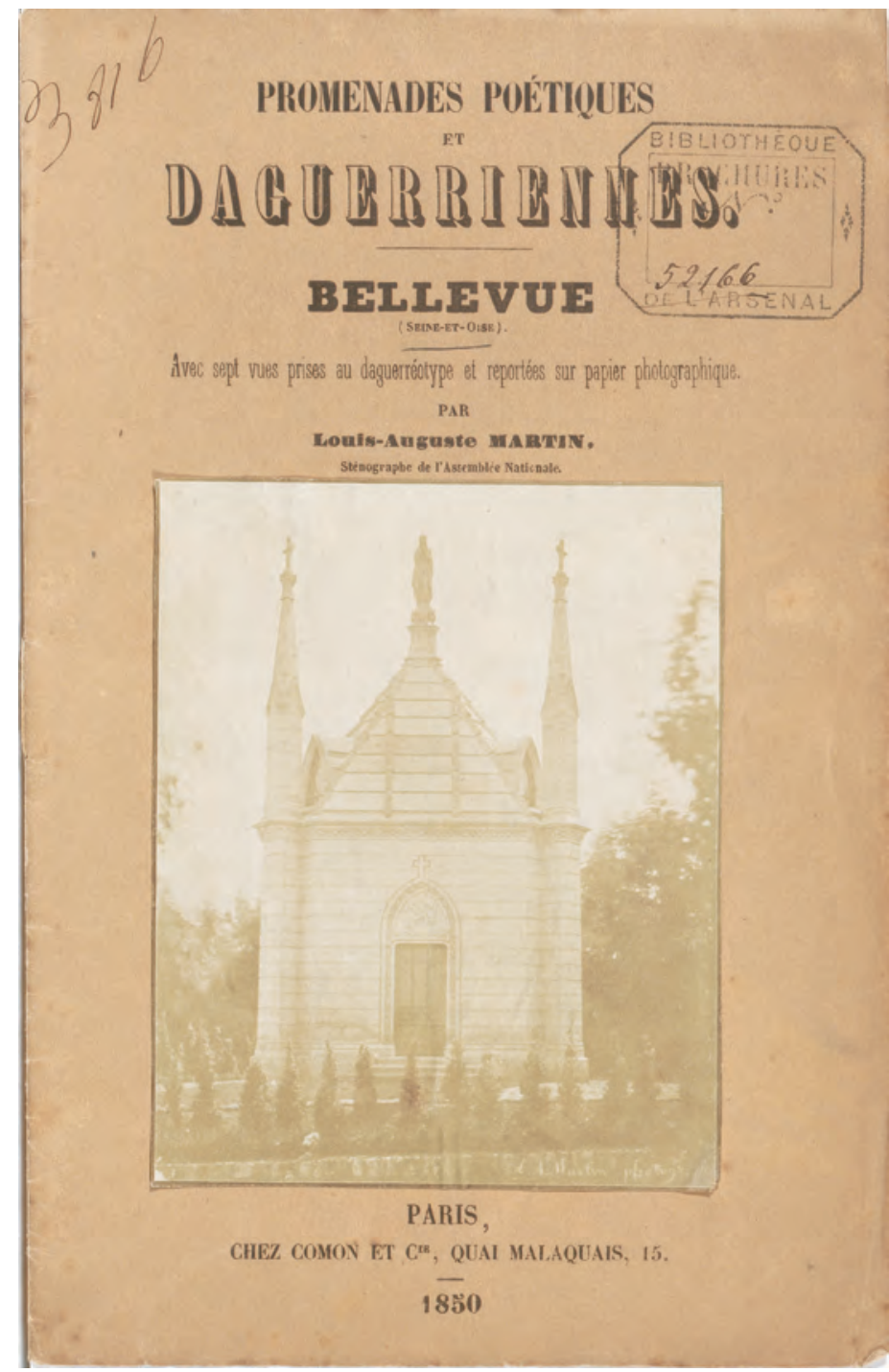

Fig. 1. Louis-Auguste Martin (18111875), Cover of Promenades poétiques et daguerriennes - Bellevue, 1850. Paper photograph, $19.0 \times 12.5 \mathrm{~cm}$. Paris: Bibliothèque nationale de France. 
subsequent composition of these impressions. In Quand le Voyage devient Promenade (2011), Philippe Antoine notes that in most cases it is understood that the traveler's account, which generally conforms to the chronology of his journey, is completed only when he returns home (40). It is not possible, he says, to synchronize the narrative of the voyage with its content or what is being narrated (61). Antoine's book examines French writers' accounts of their voyages in the first half of the nineteenth century that foreground characteristics of the Promenade such as authenticity and spontaneity. In fact, these writings display what Antoine refers to as a "rhetoric of spontaneity," a term that Wendelin Guentner utilizes to describe a mode of writing associated with nineteenth century accounts of voyages that is characterized by discontinuity and incompleteness (Guentner 13). Both Guentner and Antoine identify various strategies authors use to maintain the rhetoric of spontaneity and to mask the gap between experiences and their retelling. These include interjections, auto-corrections, and a seeming disorder of the text, among others. Martin's text employs some of these efforts to achieve a rhetoric of spontaneity, but it is his photographs that effectively diminish the perceived distance between the experience of the promenade and its relation, the Promenade. The photographs testify to the presence of the author at a specific place, which provides the reader with proof of Martin's encounter with the world. Such evidence was expected from the Promenade (Antoine 21). They also are evidence of a specific moment in the promenade when the author seemingly stopped, with a camera, to note his impressions. The photographs therefore reference the past, yet their compelling qualities allow the reader/viewer to imagine themselves there in the present. This ability to imagine being present at the places Martin visits is facilitated by the visual clarity of the photographic image, due in a large part to its detail. Text and images treat the same subjects but the photographs resist being illustrations; they fail to map onto the text because of the excess of detail. I suggest that in this visual excess, which is a fundamental quality of photographs as opposed to other mediums such as wood engravings, lies the potential for the reader/viewer to imagine narrative fragments of their own.

In Bellevue, Martin narrates a holiday spent with his wife in a village some ten kilometers southwest of Paris. As Antoine reminds us, not only is pleasure or some form of contentment the primary goal of the promenade, it is the disposition of the promeneur rather than the place that defines the Promenade $(15,11)$. Martin does mention his companion, but Bellevue is his account of what he calls "mes errantes pensées" (my wandering thoughts) (13). He mentions the books he has with him that he finds conducive to his wanderings: "Un Lamartine ou bien un Jean-Jacque [sic] [. . . ]" (13). He also mentions the materials with which to record his experiences: "du papier, un daguerréotype" 


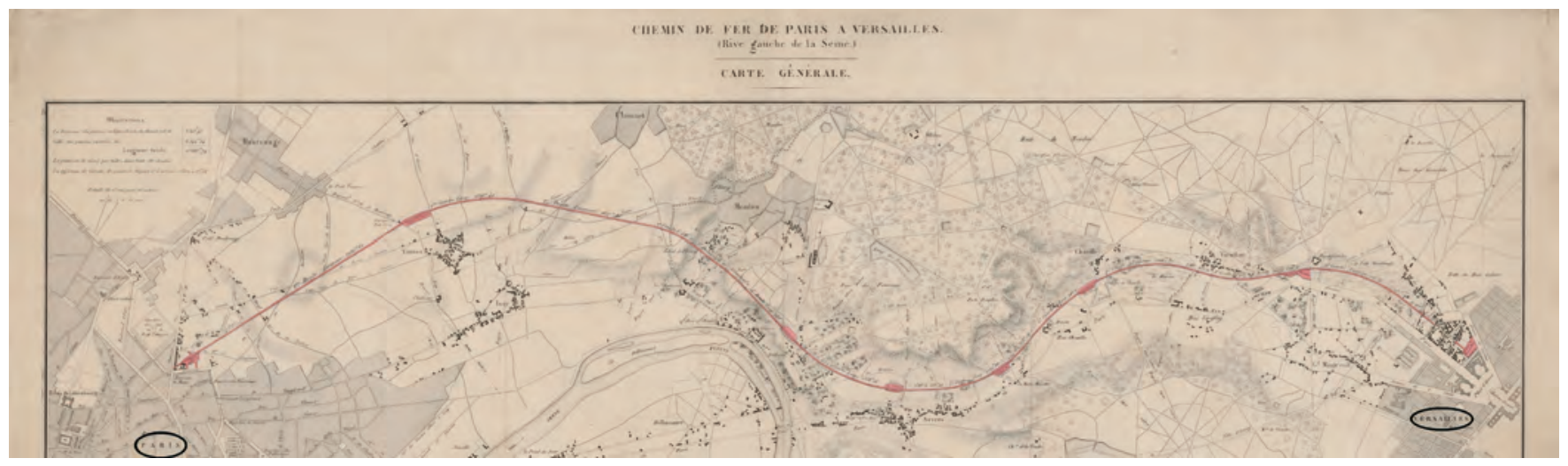

Fig. 2. Lemercier, Bernard et Cie. Chemin de fer de Paris à Versailles (rive gauche de la Seine).Carte générale, $1838.106 .0 \mathrm{x}$ $62.0 \mathrm{~cm}$. Paris: Bibliothèque nationale de France.

(3). ${ }^{8}$ Martin begins his poem by describing the desire to escape the bustling and noisy city. Soon after the train leaves Paris he is relieved to breath purer air and attentively takes in the countryside. The arc of the train's path from Paris to Versailles via the Left Bank and the stations it served were mapped out for the traveler, situating him within a prescribed route (fig. 2). Martin makes out the distinct features of the places marked on the map even as they quickly slip by: the fort of Vanves on the right, Issy behind it, and on the left Clamart hidden in the trees (fig. 3). Soon a whistle rings out, the train slows, then stops, and a voice cries out: Bellevue! Inserted below these lines announcing the arrival of the train in Bellevue is a photograph of the train tracks leading to the station (fig. 4). The attempt to visually capture the moment of arrival carries with it the attendant dislocation of train travel that Martin addresses in his verses. Once installed in his lodgings in Bellevue, Martin looks through a window to see Paris in the distance. This prompts him to consider that just a few hours earlier he was there amidst the din of the city trying to avoid the horses and carriages roaring by, and now the only sound he hears is a fly buzzing around a flowering tree. He is keenly aware that the modern city beyond, and the countryside surrounding it, are inextricably linked, in part because of the railroad, and muses about the possibility of a life in Bellevue that would offer him tranquility yet enable him to easily reach the city when necessary.

8 "Daguerréotype" here refers to the instrument or the camera rather than the process. 


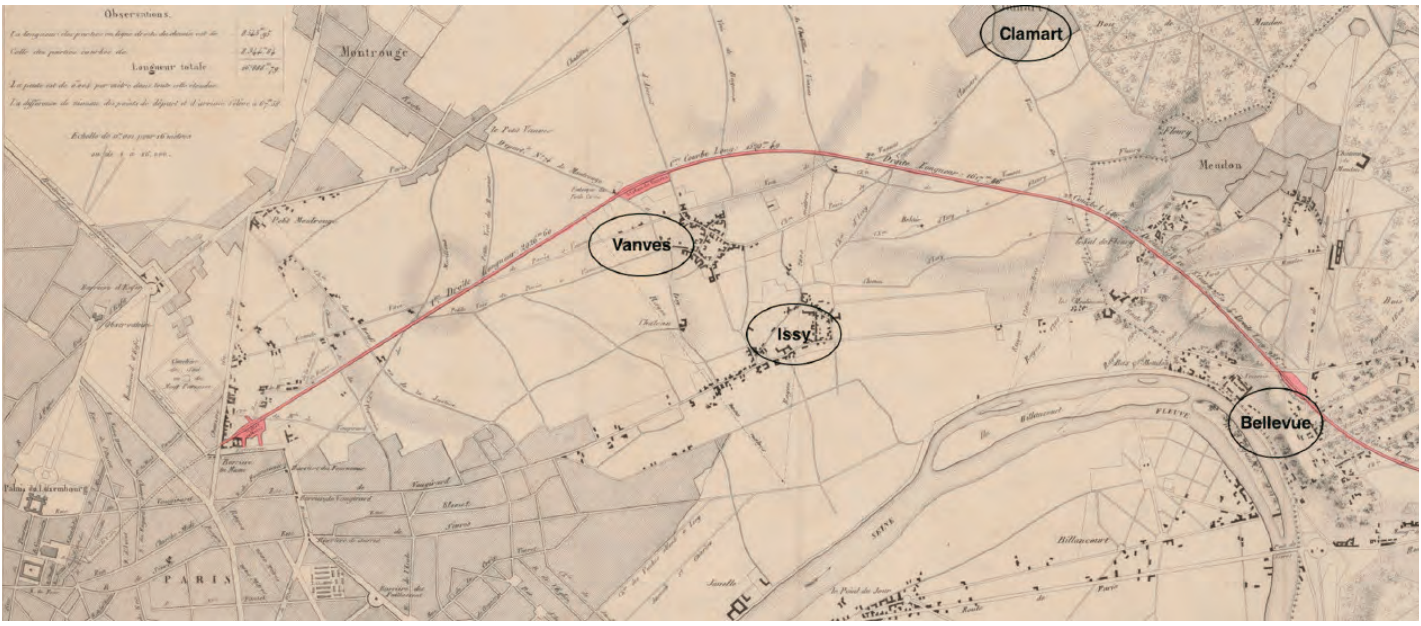

Fig. 3. Chemin de fer de Paris à Versailles (rive gauche de la Seine). Carte générale. Detail.

The train and its predetermined route are not conducive to the aleatory nature of the promenade. Only when Martin explores Bellevue and its surroundings on foot does this aspect emerge. Walking along a path near the Bellevue station, Martin comes across the small chapel of Notre Dame des Flammes (fig. 1). As in many Romantic accounts of voyages/promenades, encounters with monuments often give rise to philosophical musings, many of them reflections about time and human destiny. For Martin this chapel stands as a reminder of the sudden, tragic loss of human life and the destructive power of the machine. The chapel was erected in memory of those who died in a railway disaster that occurred nearby in 1842. The accident happened on a Sunday when the train, filled with passengers returning to Paris from Versailles, derailed moments after passing Bellevue. Over fifty people died and more than a hundred people were severely hurt. The event, which was the first significant railway disaster in France, traumatized the entire country as witnessed by the many detailed accounts of the accident and several poems that were published in the aftermath. These accounts describe the horror of men, women, and children asphyxiated, incinerated and crushed to death. Martin chose to put the photograph of the chapel on the cover of Bellevue and inserted it in the text where he speaks of those who innocently pursued pleasure and unexpectedly found death. 
Fleeing the funerary monument and the melancholy thoughts it engenders, Martin follows the turning path and comes upon a striking view of the Seine enclosing Boulogne in an arc (fig. 5). The lines of verse under the image refer directly to his taking the photograph:

Je braque ma lunette, et tout le paysage/Sur le papier, soudain, incruste son image;/Je l'emporte aussitôt, comme un bien dérobé,/Et dans mon cabinet, un instant absorbé,/Je prépare l'épreuve à passer, belle et fière,/De la lampe blafarde à la grande lumière. (I aim my lens, and the entire landscape suddenly encrusts its image on the paper; I take it straight away, like a stolen object, and in my study, I am for a moment absorbed in preparing the beautiful and proud negative to pass from the pale lamp to the bright light) (11-12). ${ }^{9}$

Martin here is in essence writing with light: héliographie. As Antoine notes, authors often make reference to writing or to taking notes during their travels in an effort to narrow the gap between the actual experience of travel and the later composition of the Promenade. In Bellevue this tension between the present and the past is heightened because while Martin's poem points to a post-promenade composition, the photographs claim to be consonant with the activity of the promenade. Martin's photograph of the Seine and his verses suggest that he was trying to visually match the immediacy and the spontaneity of suddenly coming upon the view. "Suddenly" is the word he uses to describe the rapidity with which the photographic image was made. While no photograph in 1850 was instantaneous, often this was the word used to describe the immediacy with which the image, as opposed to a drawing for example, was made..$^{10}$ The photograph, understood as an image that encapsulates a specific moment, foregrounds a concept of time that, in the mid-nineteenth century, shaped human experience. The public was increasingly aware that precise timekeeping was replacing solar time, a move that was greatly spurred by the introduction of train travel in the 1840s (Zerubavel 6). Visitors to Bellevue, for example, were obliged to consult train schedules posted in stations or published in guidebooks such as Forgame's Voyage pittoresque sur le chemin de fer de Paris à Versailles par la rive gauche de la Seine of 1840.

9 Gustave Le Gray, a photographer who, like Martin, was a member of the Société héliographique in early 1851 published a photography manual in which he defined several terms including épreuve. For Le Gray épreuve could refer to either the negative or the positive. He explicitly states that the positive is produced by exposure to the sun. Martin's refers to preparing his épreuve in dim light. Gustave Le Gray, Nouveau Traité théorique et pratique de photographie sur papier et sur verre (Paris: 1851): 14.

10 The technical demands of making a photograph in 1850 - setting up a tripod, making the exposure, and developing the negative - would necessitate a certain amount of time. Exposure times varied widely, from seconds to minutes depending upon weather and light conditions, the lenses used, and the quality of the paper. 
Fig. 4. Louis-Auguste Martin (1811-1875), Arrival at Bellevue Station, page 4 of Promenades poétiques et daguerriennes - Bellevue, 1850. Paper photograph, 6.5 $\mathrm{x} 7.5 \mathrm{~cm}$. Paris: Bibliothèque nationale de France.

$$
-4-
$$

P'us loin, de Val-Fleury le vert amphithéàtre,

Et Bas-Meudon tout blanc de poussière et de plàtre.

Mais de la grande ville à peine nous sortons,

Qu'un air plus pur déjà ravive nos poumons,

lit nos yeux, attentils à tout pays qui passe,

Dévorent avec joie et le ciel et l'espace

Un grand coup de sifflet dans les airs retentit :

A ce signal, d'abord, le train se ralentit,

Puis s'arrête,... Une voix a crié : Bef.Levve !

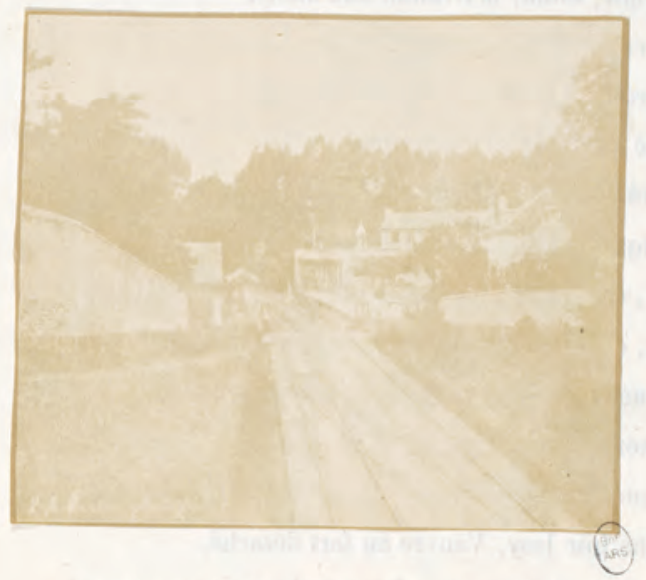

Riante station des artistes connue, 
By the early 1850s photographic images were routinely thought of as tethered to the specific moments they preserved. The writer Pierre-Henri de Lacretelle articulates this linkage in his 1853 statement that photography is the "le prolongement indéfini du regard" (the indefinite prolongation of the look) (25). And because the photograph was able to preserve the photographer's look, it enabled viewers to partake of that moment in their imaginations.

Those writing about the experience of looking at photographs, whether conscious or not, often utilized the rhetorical figure of hypotyposis to convey this ability to imagine being in the place pictured in the photograph. In his book on rhetorical figures published in 1827, Pierre Fontanier calls this a figure of style by imitation and defines it in terms of painting images:

[...] d'une manière si vive et si énergique, qu'elle les met en quelque sorte sous les yeux, et fait d'un récit ou d'une description, une image, un tableau, ou même une scène vivante (in a manner so lively and energetic, that in a way it places them before one's eyes, and turns an account or a description into an image, a picture, or even a living scene) (188).

Writings on the Diorama in the 1820s, aesthetic discourse in the 1830's, and accounts of early photography all point to the use of hypotyposis as a means of describing how the viewer's experience of seeing is amplified to the point that they can imagine moving through the spaces depicted. In 1839 the art critic and writer Jules Janin published two articles, one on the daguerreotype and one on landscape painting, that draw upon descriptions of the spectator's experience of the Diorama. His article on the daguerreotype appeared early in 1839 before the public had seen examples of Daguerre's invention. To convey the qualities of the small, detailed image on metal he implicitly links it to the illusionistic qualities of the Diorama. Janin reminds his readers of how the Diorama allows them to enter into the spaces depicted whereas before they only saw the surfaces of paintings:

Vous avez pénétré à sa suite [Daguerre] dans les vieilles églises en ruines; vous avez gravi la montagne, descendu le vallon; vous avez parcouru les fleuves et les mers; l'enchanteur vous a promené sans fatigue dans les plus curieuses capitales [. . . ] (You have followed him [Daguerre] into old churches in ruins; you have climbed the mountain, descended the valley; you have made voyages on rivers and seas; the enchanter [Daguerre] has taken you to the most curious capitals without fatigue) (Janin, "Le Daguerotype"145).

A few months later Janin published his review of the annual Salon in which he described the work of contemporary French landscape painting in much the same way as he described the Diorama, that is, 
by highlighting the viewer's ability to imagine being there. Referring to the landscapes of the painter Jules Dupré, Janin reassures his readers that:

Vous pouvez-vous asseoir au pied de ces arbres, l'arbre ne sera pas brisé; vous pouvez marcher dans ces allées sablées, l'allée n'enfoncera pas sous votre marche; vous pouvez vous plongez dans ce lac, l'eau est limpide et profonde [...] (You can sit at the foot of these trees, the tree will not break; you can walk along these sandy paths, the path will not sink beneath your step; you can dive into this lake, the water is clear and deep) (Janin, "Salon" 269).

Descriptions of this mode of looking, in which the viewer imagines 'being there,' were in France in the years around 1850 , carried over into descriptions of photographs.

Photographs taken during travels to places both near and far were particularly conducive to stimulating imagining being there. The photographic album became popular in the early 1850s beginning in 1852 with Maxime du Camp's Egypte, Nubie, Palestine et Syrie. It contained one hundred and twenty-five photographs that were separate from the introductory and explanatory texts. The idea that these photographs could amplify or enhance what Maynard calls "imagining or visualizing activities" (83) is addressed by Ernest Lacan, contributor to and editor of La Lumière, a weekly publication devoted to photography. In an article published in 1855 in Le Moniteur universel, the official newspaper of the Empire, he writes:

Vous êtes dans votre cabinet de travail, accoudé sur l'appui de votre fenêtre. C'est l'été. Votre regarde cherche, au-dessus des maison qui vous entourent de tous côtés, le coin de ciel bleu qui est tout votre horizon; et vous songez qu'il y a, sous ce même ciel dont vous ne voyez qu'un lambeau, de riantes campagnes où l'oeil se perd dans les lointaines perspectives, où la poitrine se dilate, où la pensée se transforme et s'épure, où l'âme se plonge dans les profondeurs de la rêverie, [. . .]Vous songez que vous pourriez être là au lieu d'être ici. [. . . ] Attendez! . . . Est-ce que la photographie n'est point là? . . . Ouvrez cet album[....] (You are in your study, leaning on your elbows at the window. It is summer. Above the houses that surround you, you search for that corner of blue sky that is your entire horizon; and you reflect that beneath this same sky of which you see only a bit are pleasant landscapes where the eye is lost in distant perspectives, where the chest swells, where thought is transformed and refined, where the soul is immersed in the depths of reverie, [ . . . Y You dream that you could be there instead of here. [...] Wait! . . . Is not photography there? . . Open this album) (1). 


\section{Boulogne, que la Seine enferme dans un arc,}

\section{Le Calvaire et son fort, Saint-Cloud et son grand parc.}

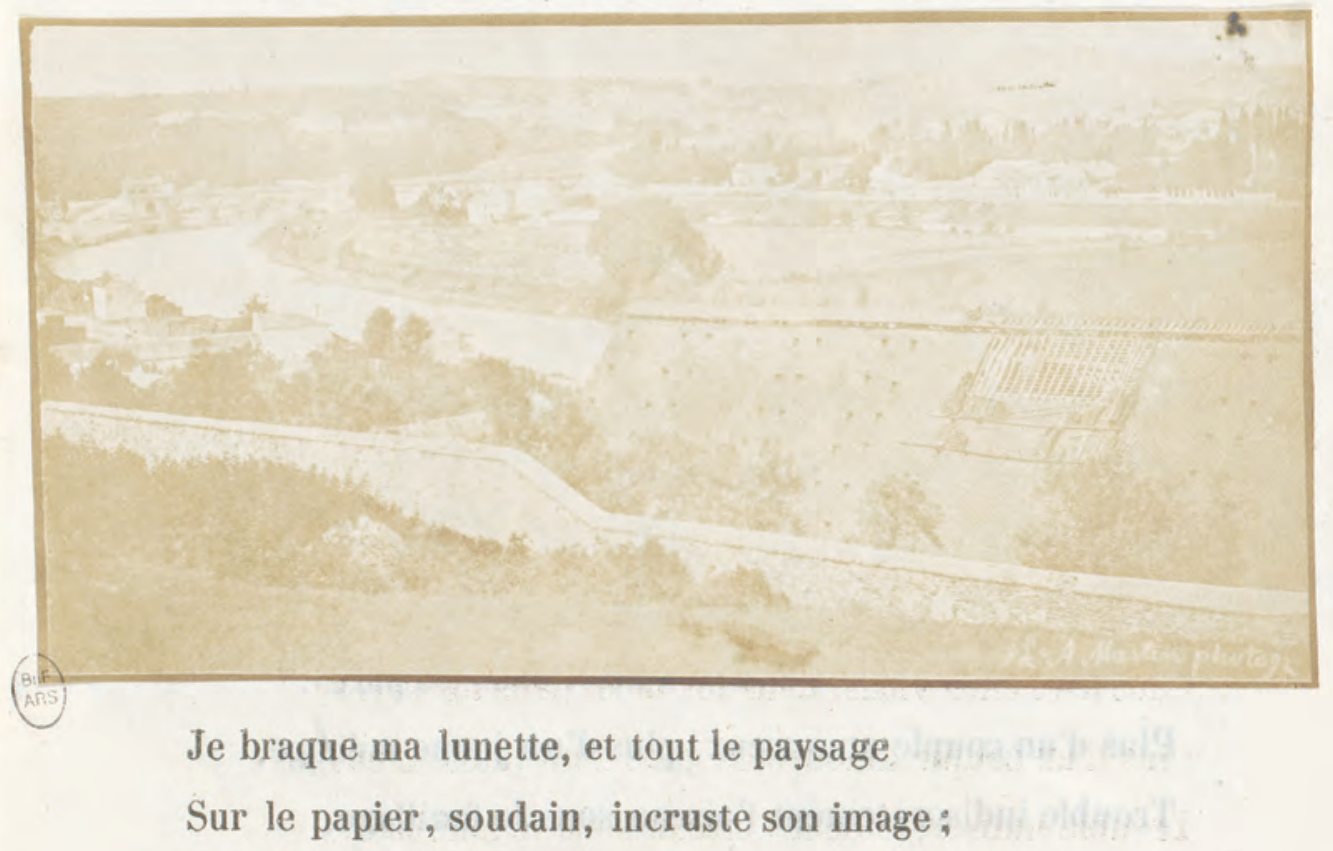

Fig. 5. Louis-Auguste Martin (1811-1875), View of the Seine River, page 11 of Promenades poétiques et daguerriennes Bellevue, 1850. Paper photograph, 6.0 x $11.5 \mathrm{~cm}$. Paris, Bibliothèque nationale de France.

As for how a photograph of a place compares to a text that describes it, that issue is addressed by Paul Nibelle in an article entitled "Photographie et les voyages" that appeared in 1854 in La Lumière. Nibelle begins by stating that it is not enough to admire the marvels of nature and art that astonish and move us; we want to share the feelings they arouse in us with others. This need, he asserts, underlies books about travel, narrative accounts, and descriptions. However, for him written accounts are not fully satisfying because while the imagination is engaged the eyes remain inactive. In contrast, he claims, a small photograph is enough to stimulate both the imagination and the senses. 
Avec quelques carrés de métal ou de papier sous les yeux, j'ai parcouru des forêts immenses, j'ai entrevu des lointains ravissants, j'ai entendu chanter les oiseaux dans les arbres, j'ai gravi de nouveau les flancs abruptes et sauvages des montagnes, j'ai recommencé les voyages que j'avais faits [sic], j'ait fait ceux que je veux faire un jour.(Looking at a few squares of metal or paper, I have travelled to immense forests, glimpsed ravishing distances, heard birds singing in the trees, climbed again steep and wild mountain slopes, I began again the voyages I had made, I did those that I want to do one day) (139)

Nibelle proposes that the writer replace his pen with a camera because, he insists, in a photograph only a few centimeters in size one may find a complete poem. Martin's strategy in Bellevue is not to replace the text with photographs but to combine the two. This raises the question about the nature of the relationship between text and photographs within the context of the poem's narration.

Martin's Bellevue, of course, is not the first work to combine photographs with text. William Henry Fox Talbot's The Pencil of Nature (1844-46), which Martin certainly knew, claims this honor. Like Martin, Talbot is both author of the text and maker of the photographs. The two works differ, however, in the presentation of the photographs, the type of text and the ways in which the photographs are linked to it. The twenty-four photographs in Talbot's six fascicles are referred to as "Plates" and presented as "Illustrations." Each is framed by a simple ruling in brown ink. Inside this frame, in the lower right corner, is an identifying number. This number corresponds to the plate number that accompanies the title of the photograph. The photographs are placed opposite the texts that refer to them. Many of the photographs are horizontal images, but in the fascicles they are oriented vertically and thus the reader is obliged to rotate the fascicle in order to see the photographs properly. Also, it is thought that there were interleaves or guard tissues placed between the image and the facing page, which would also have made it difficult to look at both image and text together. ${ }^{11}$ Talbot's texts in general serve as an inventory of the possible applications of his paper process and include technical information. As Carol Armstrong comments, "in each case it is the text that 'illustrates' the image, rather more than the other way around" (125).

Martin's text-a promenade in poetic form - is quite different from Talbot's as is the relationship between text and image. Martin's insertion of the photographs without titles and without captions between the lines of his poem aligns them with the format of the page. This mode of inserting images into the text would have been familiar to French readers at the time. A new type of wood engraving,

11 Larry Schaaf, email to author, October 4, 2017. Professor Schaaf is Director of the William Henry Fox Talbot Catalogue Raisonné, an online resource at Oxford University's Bodleian Libraries. 


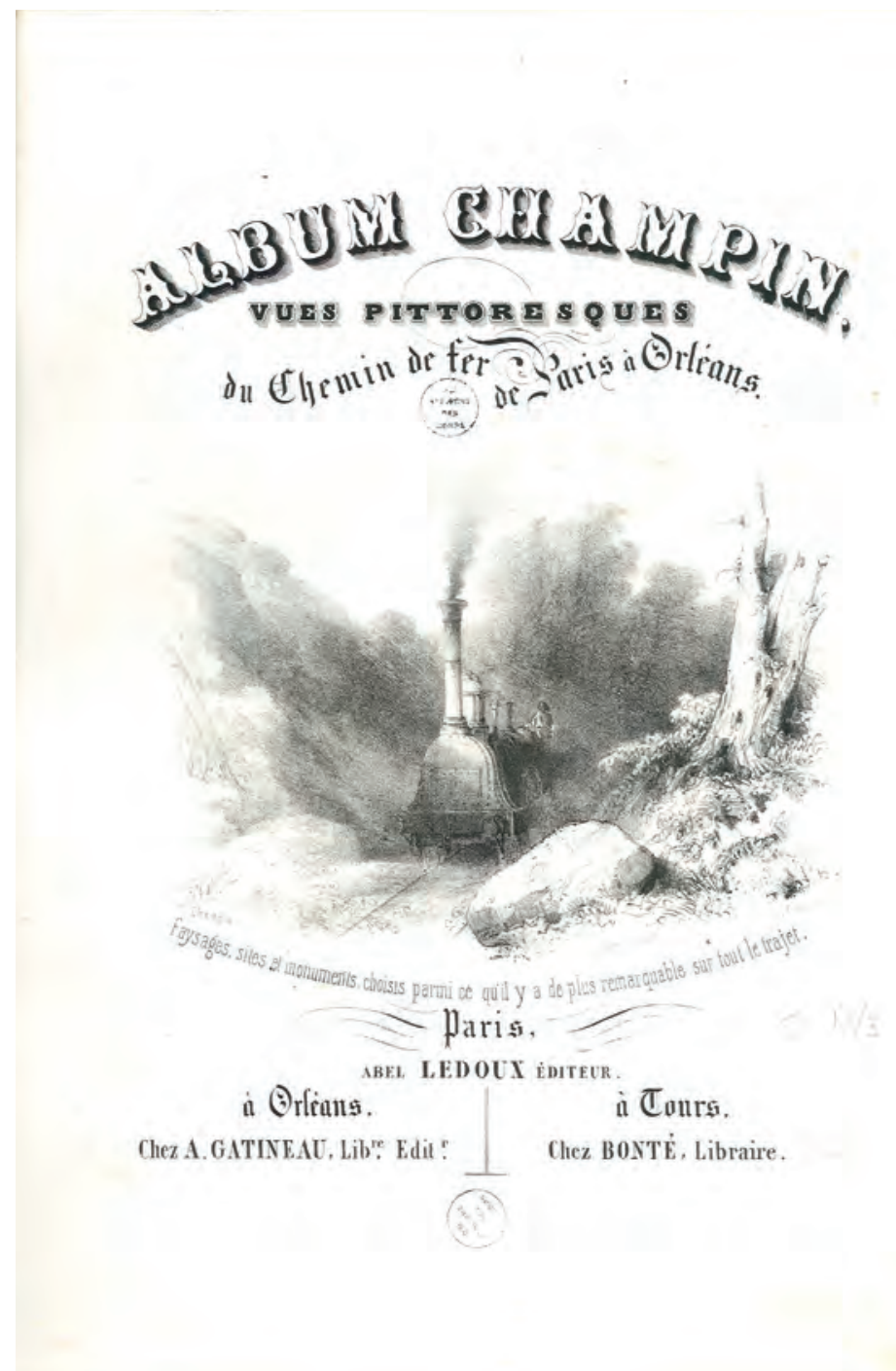

Fig. 6. Champin, Cover of Album Champin: vues pittoresques du chemin de fer de Paris à Orléans, 1840 Bibliothèque municipale de Saint-Pierre-des-Corps. 
which developed in France in the 1830s, permitted the printing of both image and typography on the same page. ${ }^{12}$ The historian Maurice Samuels comments that this page layout "breaks down the barrier between the visual and the verbal" (77). The elimination of the plate mark and the manner in which the wood engraved image fades towards its edges facilitates what Samuels describes as an almost seamless transition from text to image and back again to text. The reader, he says, is able "to assimilate both levels of content, the graphic and the scriptural, simultaneously and, as it were, effortlessly" (77). He refers to the way in which they work together as "a symphonic signification in which parallels--and disjunctures--between image and text register simultaneously" (77). Despite the mention of disjuncture Samuels insists "the visual acts as a comprehension aid by immediately translating the text into a more accessible form" (77). In Bellevue the insertion of photographs instead of wood engravings results in a physical and visual break in the continuity between text and image. The materiality of the pastedin photograph, the thin dark line that frames it, and its tonal qualities inhibit any smooth transition between reading and looking that the inked text and wood engraving facilitate.

The reader's ability to assimilate the content of both image and text simultaneously is complicated in Bellevue by two related factors. First is the rhetoric of imagining being there that is closely tied to looking at photographs of places in the early 1850s. The force of this rhetoric is due, in part, to the perceived fidelity of the photographic medium. Patrick Maynard argues convincingly that the photograph's "detail as visual clarity" amplifies our perceiving in ways quite different than with other media such as drawings (199). Precise detail is what led many to characterize the daguerreotype as a reproduction, a facsimile of nature, when it was introduced in 1839. When paper photographs began to appear consistently in France in the early 1850s that idea persisted despite the fact that the detail in paper photographs, including those by Martin, was often less sharp than in daguerreotypes. The second thing that complicates the simultaneous assimilation of photograph and text is the surfeit of visual detail, what Maynard refers to as "detail as incidental representation" (199). I would argue that because these incidental details exceed textual description they have the potential to stimulate the viewer's imaginings beyond simply imagining seeing. Martin's view of the Seine (fig. 5) is a good example of how visual clarity suggests to the reader/viewer that they are seeing what the photographer sees: the roof of the glassworks on the right, the Seine as it curves around on the left, and the landscape beyond. In another of Martin's photographs, that of the train's arrival in Bellevue (fig. 4), the framing works to enhance the ability of the reader/viewer to imagine being there by positioning them not as

12 On the development of wood engraving in France in the 1820s see Michel Melot, "Le texte et l'image," in Histoire de l'édition française. Vol. III, Le temps des éditeurs, ed. Roger Chartier and Henri-Jean Martin (Fayard/Promodis, 1990): 337-338. 
static and detached observers but fellow travelers. Martin's photograph is highly unusual because it does not depict the train. Most illustrations in guidebooks and other texts from the period tend to represent the train as it wends its way through the countryside, that is, from the point of view of an observer outside of the train. The cover of an 1840 guide book containing views along the rail line from Paris to Orleans is typical of how train travel was represented during this period (fig. 6). The Paris to Orleans guide shows the train coming through a wooded area towards the viewer who is positioned to the side of the tracks. The image conforms to the aesthetic of the "vues pittoresques" that the guide's title promises. With its unobstructed view of the train tracks and the station of Bellevue Martin's photograph is unique in its attempt to stimulate the sensation of arriving in the reader/viewer. The details in all the photographs in Bellevue contribute to the ability to imagine being there. They also demand a prolonged looking that essentially interrupts the reading of the text. Furthermore, incidental details are also potential stimuli of imaginings of that extend or elaborate the text: narrative fragments. An example is the photograph of a row of houses in Bellevue that is inserted between the lines in which Martin refers to his lodgings (fig. 7).

He describes the house where he is staying as "Un modeste réduit, dans un coin du village" (a modest lodging in a corner of the village) (5). The line of verse above the photograph refers to the trees that shade the house; in the line below the photograph the author declares: "Nous y voilà blottis comme

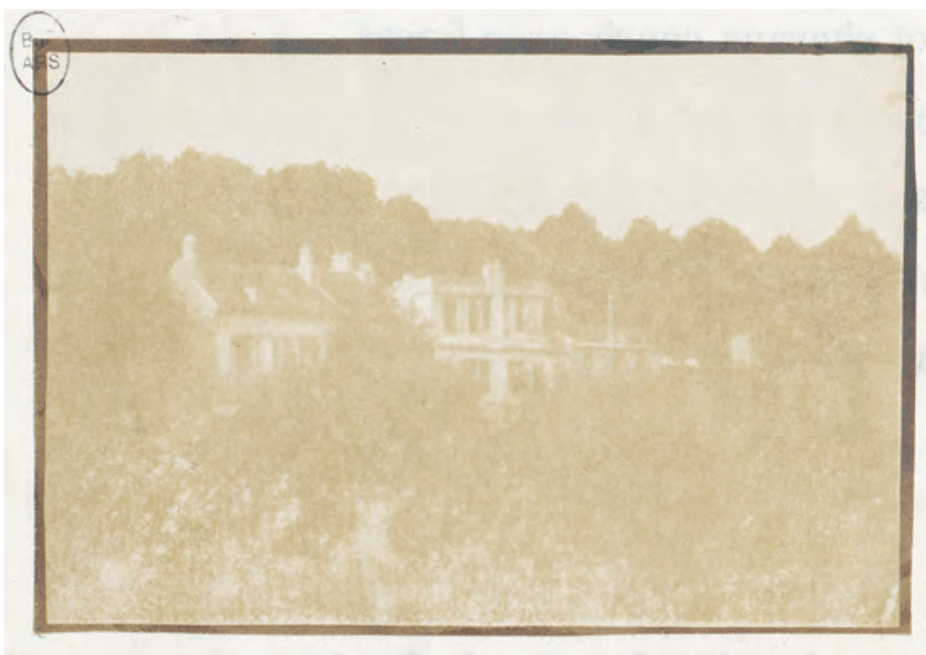

Fig. 7. Louis-Auguste Martin (18111875), Houses at Bellevue, page 5 of Promenades poétiques et daguerriennes - Bellevue, 1850. Paper photograph, 4.5 $x 7.5 \mathrm{~cm}$. Paris: Bibliothèque nationale de France. 
en un nid d'oiseau" (Here we are curled up as in a bird's nest) (5). The reader is made to understand that the photograph depicts the house where Martin and his wife stayed, but which one is it? Is it the one in the center? Perhaps, but the viewer may equally be drawn to the details of the houses flanking it and may be stimulated to imagine their interiors and the lives of those who inhabit them. This is different from the process that Wendelin Guentner describes in her discussion of the "esquisse verbale" in travel accounts. She argues that the blanks in seemingly improvised and fragmentary texts solicit the participation of the reader who is invited to imagine the details that are omitted (20). In contrast Martin's photographs contain a surfeit of detail that exceeds his concise and measured verses and invites the reader/viewer to imagine narrative fragments and append them to the poem.

Bellevue was unique in its combination of text and photographs when it was published in 1850. It was created at a moment when early practitioners of photography such as Martin were simultaneously attempting to situate the medium within existing cultural practices and exploring ways in which it might expand them. Bellevue is a Promenade poétique but also a Promenade daguerrienne. Martin clearly thought that photographs were compatible with a literary form that is characterized by its aleatory nature and the concomitant spontaneity that is part of this wandering. His choice of title and the way in which he placed the photographs in between the lines of the poem without titles speaks to his intent to consider them as more than illustrations of the text. As both an author and a practitioner of photography Martin was in a unique position to think about them as each participating in the narration of his promenade. While Martin's text maps out the trajectory of the promenade his photographs literally interrupt the text to call attention to those places where the author stopped and looked. This emphasis on the immediacy of experience foregrounds the tension between the promenade and its later retelling. The photographs are compelling invitations to the reader to imagine being there and thus seemingly collapse past and present. As to what stimulated Martin to think about photographs as narrative elements we can only speculate. As a member of the Societé héliographique who often transcribed the minutes of the group's meetings he was well aware of the discussions taking place about the nature of photography and its potential uses. At the Société's meeting held on April 4, 1851 the painter and photographer Jules Ziegler took stock of the progress of photography and ventured to situate it with regard to existing modes of communication. Ziegler, encouraged by the prospect of a photographic printing establishment in France and thus the proliferation of photographs, stated that the moment had arrived when photography was becoming, like printing and writing, a third means of conveying our thoughts (38). Lous-Auguste Martin's Promenades poétiques et daguerriennes-Bellevue may be thought of as one of the earliest attempts to explore that idea. 


\section{Works Cited}

ANTOINE, Philippe. Quand le voyage devient promenade. Ecritures du voyage au temps du romantisme. Paris, PU de Paris-Sorbonne, 2011.

ARMSTRONG, Carol. Scenes in a Library: Reading the Photograph in the Book, 1843-1875. Cambridge, MA and London, MIT Press, 1998.

DU CAMP, Maxime. Egypte, Nubie, Palestine et Syrie. Dessins photographiques recueillis pendant les années 1849, 1850 et 1851, et accompagnés d'un texte explicatif par Maxime du Camp. Paris, Gide et J. Baudry éditeurs, 1852.

FONTANIER, Pierre. Des Figures du discours autres que les tropes. Paris, Maire-Nyon, 1827.

FORGAME, Voyage pittoresque sur le chemin de fer de Paris à Versailles par la rive gauche de la Seine. Paris, 1840.

GUENTNER, Wendelin. Esquisses littéraires: rhétorique du spontané et récit de voyage au XIXe siècle. SaintGenouph, Librairie Nizet, 1997.

JANIN, Jules. "Beaux-Arts. Le Daguerotype [sic]." L'Artiste 2.2 ,1839, pp.145-148.

JANIN, Jules. "Salon de 1839 (cinquième article).Paysages, Marines." L'Artiste 2.20, 1839, pp. 269-276.

LACAN, Ernest. «De la photographie et de ses diverses applications aux beaux-arts et aux sciences.» Le Moniteur universel, 12 janvier 1855, pp. 1-3.

LACRETELLE, Pierre-Henri de. "Albums photographiques. No. 1. M. Nègre. "La Lumière, 12 fév. 1853, pp. 25-26.

MARTIN, Louis-Auguste. Promenades poétiques et daguerriennes: Bellevue. Paris, chez Comon et Cie, 1850.

MAYNARD, Patrick. The Engine of Visualization: Thinking Through Photography. Ithaca and London, Cornell UP, 1997.

NIBELLE, Paul. “La photographie et les voyages.” La Lumière, 2 sept. 1854, pp. 138-139.

SAMUELS, Maurice. The Spectacular Past: Popular History and the Novel in Nineteenth-Century France. Ithaca and London, Cornell UP, 2004.

TALBOT, William Henry. The Pencil of Nature. London, Longman, Brown, Green and Longmans, 1844-1846 (facsimile 1989).

VAPEREAU, G. Dictionnaire universel des contemporains contenant toutes les personnes notables de la France et des pays étrangers. Paris, Librairie La Hachette et Cie, 1865.

WEY, Francis. «Publications héliographiques II.» La Lumière, 5 août 1851, pp. 102-104. 
ZERUBAVEL, Eviatar. "The Standardization of Time: A Sociohistorical Perspective." American Journal of Sociology, July 1982, pp.1-23.

ZIEGLER, J. [Jules]. "Société héliographique. Séance du 4 avril. Présidence de M. J. Ziegler." La Lumière, 13 avril 1851, p. 38. 